\title{
Hawai'i's food consumption and supply sources: benchmark estimates and measurement issues
}

\author{
Matthew K Loke $e^{1,2^{*}}$ and PingSun Leung
}

\footnotetext{
* Correspondence: loke@hawaii.edu ${ }^{1}$ Department of Natural Resources and Environmental Management, University of Hawai'i at Mänoa, 1910 East-West Road, Sherman 101, Honolulu, Hawai'i 96822, USA 2Hawai'i Department of Agriculture, Agricultural Development Division, 1428 South King Street, Honolulu, Hawai'i 96814, USA
}

\begin{abstract}
At the current time, Hawai'i lacks an established set of benchmark estimates on the availability of food for market consumption and its supply sources. This paper serves to fill a persistent gap in the existing literature by providing an estimation framework to map the existing food supply flows from various sources and to determine the various levels of food consumption in Hawai'i. The authors suggest modified measures of food self-sufficiency and import dependency to provide a more accurate assessment on the extent of food localization in Hawai'i. The analytical framework presented in this paper can be applied to other small, open (island or regional) economies with a food localization agenda, as it provides a more discrete and appropriate set of measurements, as well as offering the lessons gained through Hawai'i's experience and challenges in the data-collating process.

Local production and imports (continental United States and foreign countries) of consumable food in Hawai'i are estimated at just over 1.14 million tonnes in 2010. Food exports totaled 175.5 thousand tonnes, leaving total available food for consumption locally at 966.6 thousand tonnes. On a de facto basis, per capita food consumption in Hawai'i is estimated at 657.9 kilograms in 2010. At the food group level, fresh vegetables lead with per capita food consumption of 84.2 kilograms, followed by other proteins at 69.1 kilograms, fresh fruits at 67.7 kilograms, fresh milk at 62.9 kilograms, and rice at 27.9 kilograms.

The analysis indicates that Hawai'i has an overall food self-sufficiency ratio (SSR) of $15.7 \%$ and an overall food import dependency ratio (IDR) of $102.5 \%$. While it appears counterintuitive that the IDR exceeds $100 \%$, this figure actually indicates the existence of food imports into Hawai'i that are then turned around and re-exported to other markets. With application of the more accurate localization ratio (LR), we estimate that only $11.6 \%$ of available food for consumption in Hawai'i was actually sourced from local production in 2010. Likewise, the modified import dependency ratio (MIDR) indicates that an estimated $88.4 \%$ of available food in Hawai'i was sourced from imports.
\end{abstract}

Keywords: Food consumption; Supply sources; Benchmark estimates; Food self-sufficiency; Food localization; Import dependency

\section{Background}

In the aftermath of the Great Recession of 2007-2009, public concern, interest, and debate on food security and food self-sufficiency has intensified in Hawai'i and elsewhere in the United States. This concern is real and understandable, considering Hawai'i's geographic isolation in the Central Pacific Ocean, looming threats of global warming

(c) 2013 Loke and Leung; licensee Springer. This is an Open Access article distributed under the terms of the Creative Commons Attribution License (http://creativecommons.org/licenses/by/2.0), which permits unrestricted use, distribution, and reproduction in any medium, provided the original work is properly cited. 
and climate change, and the 2008 food crisis, which showed serious vulnerabilities in the global food system. Hawai'i's supply of food, as it presently exists, is vulnerable to disruptions in the shipping chain, production fluctuations in the continental United States, severe weather conditions, and sudden spikes in the prices of food products, as well as higher prices for fuel, feed, fertilizers, and other agricultural "inputs." During the 2008 food crisis, the surge in food price inflation worldwide was caused primarily by rising oil prices, depreciating U.S. dollar, increasing demand for biofuels, and export restrictions imposed by leading food producing countries (Heady and Fan 2008). In some quarters, there is a genuine desire to dissociate local food prices from the rising global oil price.

In order to start a meaningful discussion on food security or food self-sufficiency in Hawai $i$, we must have a reasonably good assessment of the consumption level of food groups, the characteristics of food consumed, and its origins or supply sources. In 1937, H.H. Warner, then Director of the Agricultural Extension Service, Territory of Hawai $i$, wrote on the character and variety of foods consumed by people on the Islands. He described the unique situation in Hawai i: "Probably nowhere else in the world is there to be found a group of similar racial proportions with as distinctly varied diet habits, isolated from a large part of their natural food supply." While changing diets have evolved since then, including the creation of Euro-Asian cuisine and the Hawai'i Regional Cuisine movement, Warner's insightful comment is still valid and relevant today.

At the current time, Hawaii lacks an established set of benchmark estimates on the availability of food for market consumption and its supply sources. This paper serves to fill that persistent gap in the existing literature and proposes to present available facts and a logical empirical methodology to establish definitive estimates on various food groups consumed from local and import sources. Hence, the two primary objectives in this paper are as follows: (1) map existing food supply flows and to determine the various levels of food consumption in Hawai i; and (2) suggest modified measures of food self-sufficiency and import dependency to provide a more accurate assessment on the extent of food localization in Hawai i.

The amount of food consumed in Hawai'i that is sourced from imports is not readily available. This deficiency is due to the difficulties in reconciling the various data sources on food imports and food expenditures. For example, interstate trade flow data are rather rudimentary, unlike customs data on foreign imports, which are fairly disaggregated. The problem is further complicated by the conversion of data consistently from the various sources to a common baseline in the supply chain (Leung and Loke 2008).

Despite these challenges, various local studies have been conducted. A Rocky Mountain Institute study estimated the import share of food in the County of Hawai'i at 85\% (Page et al. 2007). Likewise, popular food system analyst, Ken Meter, estimated that more than $90 \%$ of Hawai'i's food is imported (Halweil 2004). Later, the Ulupono Initiative estimated that Hawai'i consumers spend only $8 \%$ of their food budget on locally grown food, while spending the rest on imports (Ulupono Initiative 2011). Then, the University of Hawai'i at Hilo produced a Hawai'i Island food self-sufficiency scorecard that estimated the percentage of locally produced food consumed by commodity group, ranging from $0 \%$ for grains to $95 \%$ for fresh milk (Melrose and Delparte 2012). Recently, the state planning office, in a report on "increased food security and food self- 
sufficiency strategy," noted that $85-90 \%$ of Hawaii's food is imported (OP-DBEDT 2012). These estimates have been widely cited despite lingering questions about and critiques of their methodologies and estimated parameters. In comparison, the food self-sufficiency measure for the New England states is estimated at 27\% in 1997 (Holm et al. 2000).

\section{Methods}

\section{Data requirements and food groups}

The apparent consumption or total supply of food availability in Hawai' $i$ is defined as local food production plus food imports (continental United States and foreign countries) less food exports (continental United States and foreign countries). Likewise, per capita food supply is assumed to be identical to per capita food consumption in the local market. All metrics and statistics in this paper refer to food available for human consumption in product weight (kilograms). While there are alternate unit measures, such as the dollar value, calorie value, and nutritional value, we nevertheless invoked Occam's razor by utilizing the weight measure to keep the overall analysis as simple as possible, without distorting reality or sacrificing accuracy. The measure of food self-sufficiency in dollar value could contribute to unintended results that are counterintuitive to the overall concept itself. Beyond this, one pound of prime beef steak is clearly worth more in dollar value, calorie value, and nutritional value than one pound of rice. Higher-quality products also cost more in monetary value for the same weight measure. For example, a pound of beef steak with a USDA Prime label will cost more than a pound of beef steak labeled USDA Choice or USDA Select. And finally, most waterborne shipping data are published in weight measures, making weight the obvious choice in the data collating process.

We emphasize that it is not the use of calorie value and nutrition value is inappropriate or unsophisticated; it is that the adoption of calorie and nutrition measures may differentiate food commodities unnecessarily, and adds levels of complexity to the entire estimating process. For example, equivalent weight measures of fresh asparagus, frozen asparagus, cooked asparagus, and canned asparagus will have varying levels of calorie and nutrition. It is possible to make the same argument for the different varieties of asparagus (white, green, purple, and wild). Furthermore, other researchers have argued that where and how the produce is grown (in fertile versus arid lands; using various cultivation practices), processed, transported, stored, and prepared will influence calorie and nutrition values.

This paper adopts the five major food groups - dairy, grains, protein, fruits, and vegetables, as defined in the USDA My Plate concept (see Figure 1). However, the aggregate estimate for overall food consumption in Hawai'i includes one additional residual food group, which includes oils and fats, sweeteners, and others less discernible food subgroups. No beverage products (e.g., soft drinks, liquor, coffee, tea and water) are included. The consumption estimates of food groups for the entire state of Hawaici (not by county or island) are presented in total consumption and per capita consumption in weight measure. To estimate per capita consumption, the total weight estimate is divided by the de facto population in Hawai'i as of 2010, which takes into account, residents, stationed military personnel and dependents, and tourists visiting in the state.

Given the amount of available food in total and the components sourced from local production and imports, we can estimate the extent of total available food that is 


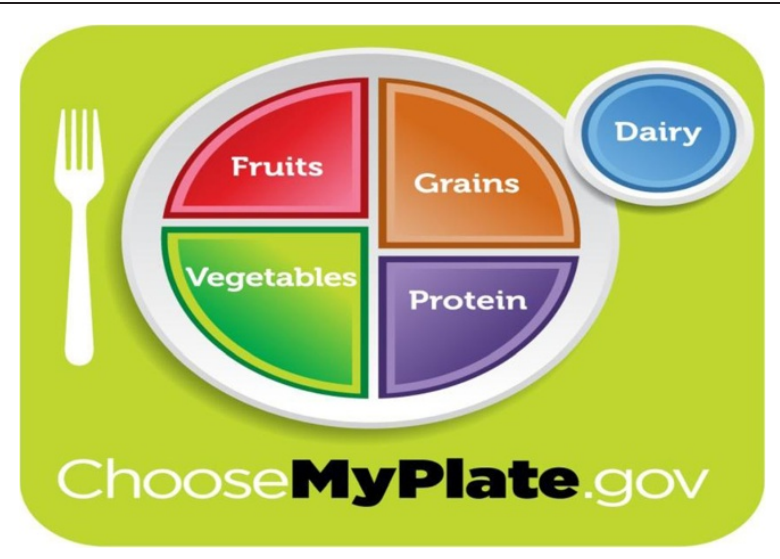

Figure 1 My plate illustration of primary food groups.

Source: USDA, 2011 (http://www.choosemyplate.gov).

satisfied by local production and by imports. Two measures commonly used in the existing literature are the self-sufficiency ratio (SSR) and the import dependency ratio (IDR). The Food and Agricultural Organization of the United Nations (FAO) defines SSR as the share of domestic production in relation to domestic food utilization, excluding stock changes, and IDR as the share of imports in relation to domestic food utilization, excluding stock changes (FAO 2001).

Several studies have utilized the SSR to analyze the structural changes of regional agricultural and food sectors. In Southeast Asia, SSRs on three categories (cereals, food, and agriculture) were employed to document the results of agricultural policy changes in Malaysia and Thailand during the 1970s and 1980s (Fitzpatrick 1991). Essentially, all three categories measured were variants of domestic commodity production divided by total domestic consumption. Malaysia saw its self-sufficiency in food increasing and self-sufficiency in cereal declining following policies to diversify its food base and displacing rice production. On the other hand, Thailand consolidated its position as a major rice exporter within a free market framework and attained higher SSRs in all three categories.

Kako (2009) defined the SSR on a calorie basis as the ratio of calorie supply from domestically produced food to the total calorie supply from all food in a country. The author found Japan's food self-sufficiency (calorie basis) decreased sharply from 79\% in 1960 to $40 \%$ in 2005 . The finding was attributed to a sharp appreciation of the Yen (increase purchasing power of food imports) and drastic changes in the diet of Japanese consumers.

Alternately, the SSR on a value basis is calculated as the proportion of consumer demand that is met by local production in terms of household food expenditures and farm-gate value (Holm, et al. 2000; DEFRA 2008). The former study found the overall food self-sufficiency level unchanged at $27 \%$ in the New England region in both 1975 and 1997 while the latter study found self-sufficiency for all food in the United Kingdom decreased from $76 \%$ in 1995 to $61 \%$ in 2008. Additionally, an earlier DEFRA study pointed out that since the SSR for the United Kingdom was calculated by market value, not by product weight or calorific content, it was prone to distortion, given the volatility of market prices and currency exchange rates during that time period analyzed (DEFRA 2006). 
In a study of food self-sufficiency and the green revolution in India, De Janvry and Sadoulet (1991) utilized the IDR (weight basis), instead of the traditional SSR. The authors found that self-sufficiency levels for wheat, rice and coarse grains increased following the green revolution in India but without improving the nutrition requirement of its population. Kendall and Petracco (2009) defined the weighted food IDR (WIDR) as the ratio of imports to consumption in product weight for various countries in the Caribbean Basin. They found food import dependency for countries in that region (1990 to 2000) could be divided into three categories: low (WIDR<30\%); medium $(30 \%<\mathrm{WIDR}<50 \%)$; and high (WIDR $>50 \%)$.

Another study on the assessment of food sustainability in Israel provided an insightful discussion on the computed IDR measure that exceeded 100\% (Gordon 2011). The author concluded that this result arises whenever exports are dependent on imports or when a certain component of an export product is imported. A relevant example here is the export of jams, which is dependent on the import of raw sugar as an ingredient. In 2008, Israel recorded IDRs for the following commodities - chicken and turkey (0.1\%), beef (66\%), fish (85\%), bread and cereals (102\%) and sweets (160\%).

Both the SSR and IDR are measurable for individual food groups and aggregated groups or total. In general, we can define SSR and IDR as follows:

$$
\begin{aligned}
S S R & =\frac{P}{P+M-X} \cdot 100 \%(\text { Equation } I) \\
I D R & =\frac{M}{P+M-X} \cdot 100 \%(\text { Equation } I I)
\end{aligned}
$$

where $P=$ local production of food; $M=$ food imports; and $X=$ food exports.

However, as shown in a later section, both measures need to be modified in order to accurately assess the extent of total food available that is satisfied by local production and by imports.

\section{Data components and sources}

In order to assess and provide a systematic estimate of food available for consumption in Hawai' $i$, it is necessary to first define, establish, and measure the various flows in the food supply chain. Various product flows from different sources of origin must be identified and measured at both disaggregated and aggregated levels and then grouped appropriately into a food supply matrix. Figure 2 provides a simplified illustration of this dynamic flow and food supply chain construction.

Available food from local production and imports (different group, form, and origin) are aggregated and netted out for exports (continental United States and foreign

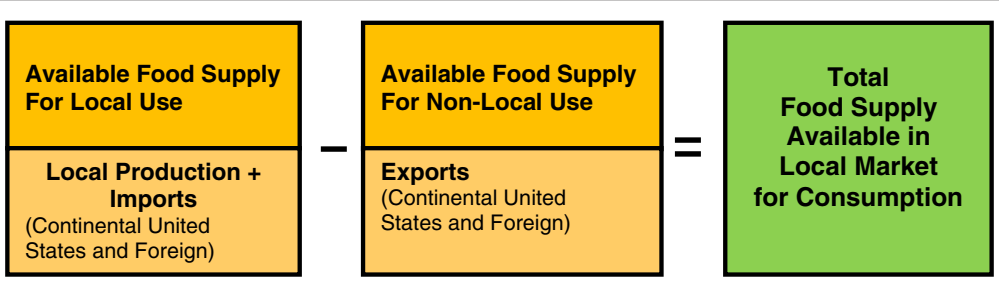

Figure 2 Hawai'i's food availability data construction chart. 
countries) to arrive at the total food supply available for consumption in Hawai i. All the necessary information is drawn from a variety of data sources, including federal and state government agencies, non-government organizations, educational institutions, cargo carriers (personal communication), wholesalers (personal communication), retailers (personal communication), industry trade groups, and independent consultants.

In this paper, the three primary sources of commercial food by origin in product weight are as follows: 1) local production data from the U.S. National Agricultural Statistics Service (NASS 2012); 2) U.S. interstate shipments data from the U.S. Army Corps of Engineers, Waterborne Commerce Statistics Center (ACE-WCSC 2012); and 3) foreign imports and exports data from the U.S. Foreign Agricultural Service (FAS 2012). Per capita consumption statistics are obtained from various sources, including the U.S. Department of Agriculture's Economic Research Service (ERS), the U.S. Census Bureau, and various Hawai'i state reports.

\section{Results}

\section{Food supply analysis}

Given Hawai'i's rapid urbanization ${ }^{\mathrm{b}}$ in one of the most geographically isolated areas, residents are naturally concerned about their overall food supply. Generally, this is not measurable until we can ascertain the group, type, and proportion of food consumed that is sourced locally and outside the state. This gives credence to the establishment of benchmark measures for the group (e.g., protein), type (e.g., beef), origin (e.g., continental United States), form (e.g., chilled), and quantity (e.g., weight) of food consumed in Hawai'i.

At the highest aggregated level, Figure 3 shows the food supply source and the demand destination by weight in Hawai i, 2010. Local production accounts for just 13\% of the total supply of 1.14 million tonnes of consumable food. A majority of the food sourcing $(81 \%)$ is from the continental United States, while the remaining $6 \%$ is from foreign countries. On the demand side, consumption in the local market accounts for 971 thousand tonnes or $85 \%$ of the total sourced food. Exports to the continental United States stand at $14 \%$, and the residual $1 \%$ is shipment to foreign countries.

Focusing on local commercial production, fresh fruits account for $38.9 \%$ of the total, followed by fresh vegetables at $26 \%$ and protein at $24.7 \%$. Figure 4 shows this

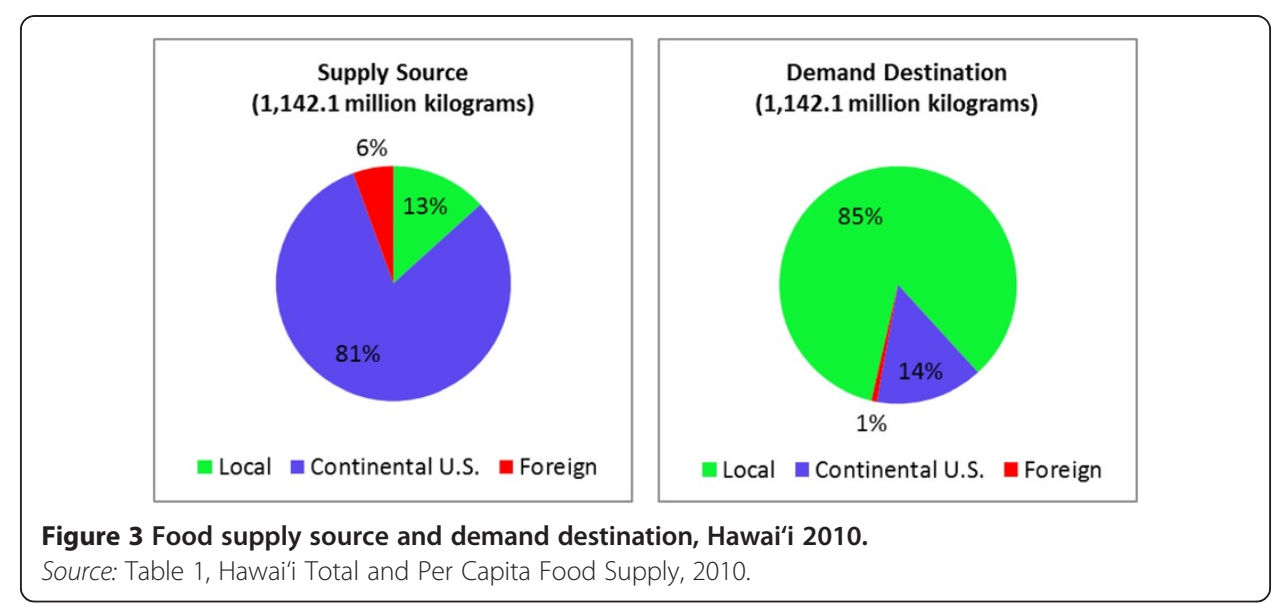




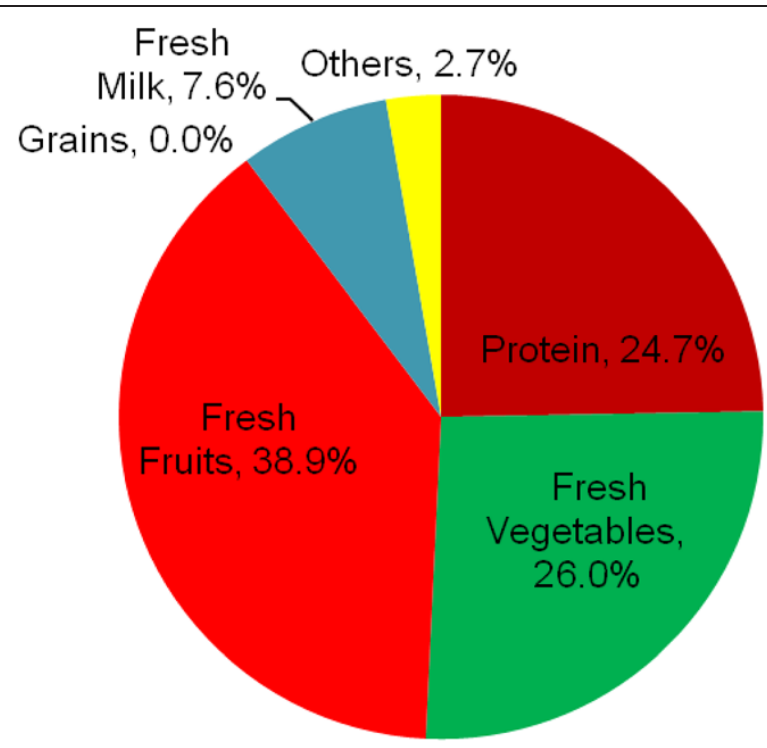

Figure 4 Distribution of local production by select food group, Hawai'i 2010.

Source: NASS (2012) Hawai'i statistics. U.S. Department of Agriculture, National Agricultural Statistics Service.

distribution by weight of the various food groups. Fresh milk accounts for $7.6 \%$ of the total, while no commercial grain production is available.

The definition of "food" applied here includes all groups (proteins, fruits, vegetables, grains, and dairy). However, due to the paucity of data as encountered in the data collection process, it was necessary to modify the food groups and to focus strictly on fresh and chilled forms of food products. Hence, food products in other forms (frozen, canned, dried, etc.) were aggregated into the residual food group "Others."

Table 1 presents the total food supply estimates for the local Hawai'i market in 2010, broken down by different food groups. ${ }^{\mathrm{c}}$ The core food groups include seafood (protein),

Table 1 Hawai'i total and per capita food supply ${ }^{1}, 2010$

\begin{tabular}{|c|c|c|c|c|c|c|c|}
\hline \multirow[t]{2}{*}{$\begin{array}{l}\text { Food } \\
\text { group }\end{array}$} & \multirow[t]{2}{*}{$\begin{array}{l}\text { Local production } \\
\text { (million kilograms) }\end{array}$} & \multicolumn{2}{|c|}{$\begin{array}{c}\text { Imports } \\
\text { (million } \\
\text { kilograms) }\end{array}$} & \multicolumn{2}{|c|}{$\begin{array}{c}\text { Exports } \\
\text { (million } \\
\text { kilograms) }\end{array}$} & \multicolumn{2}{|c|}{ Available food } \\
\hline & & U.S. & Foreign & U.S. & Foreign & $\begin{array}{c}\text { Total (million } \\
\text { kilograms) }\end{array}$ & $\begin{array}{l}\text { Per capita }{ }^{2} \\
\text { (kilograms) }\end{array}$ \\
\hline $\begin{array}{l}\text { Protein - } \\
\text { seafood }\end{array}$ & 14.4 & 1.2 & 10.8 & 1.5 & 0.3 & 24.6 & 16.7 \\
\hline $\begin{array}{l}\text { Protein - } \\
\text { others }\end{array}$ & 23.1 & 97.4 & 5.3 & 23.9 & 0.5 & 101.5 & 69.1 \\
\hline $\begin{array}{l}\text { Vegetables } \\
\text { - fresh }\end{array}$ & 39.5 & 83.9 & 2.5 & 2.2 & 0.0 & 123.7 & 84.2 \\
\hline $\begin{array}{l}\text { Fruits - } \\
\text { fresh }\end{array}$ & 59.0 & 58.1 & 2.4 & 19.8 & 1.9 & 97.8 & 67.7 \\
\hline Grain - rice & 0.0 & 47.0 & 3.3 & 9.2 & 0.0 & 41.0 & 27.9 \\
\hline Milk - fresh & 11.4 & 80.9 & 0.0 & 0.0 & 0.0 & 92.4 & 62.9 \\
\hline Others & 4.2 & 558.0 & 39.5 & 110.3 & 5.9 & 485.6 & 296.1 \\
\hline Total $^{3}$ & 151.7 & 926.7 & 63.8 & 166.9 & 8.6 & 966.6 & 657.9 \\
\hline
\end{tabular}

Notes: ${ }^{1}$ Primary sources: NASS (2012) Hawai'i statistics. U.S. Department of Agriculture, National Agricultural Statistics Service; ACE-WCSC (2012) Navigation data center - domestic U.S. waterborne traffic, part 4, 2010; U.S. Army Corps of Engineers, Waterborne Commerce Statistics Center; FAS (2012) Global agricultural trade system (GATS) U.S. Department of Agriculture, Foreign Agricultural Service. ${ }^{2}$ Based on de facto population of 1.47 million. ${ }^{3}$ Subject to rounding errors. 
other proteins, fresh vegetables, fresh fruits, rice (grain), fresh milk (dairy), and others (catch all). The estimates are expressed in the various source components (local production, imports, and exports) and measured by product weight in kilograms. Fresh fruits, fresh vegetables, and other proteins are the three largest food groups sourced from local production. Other proteins, fresh vegetables, and fresh milk are the largest import components. Combined, the leading available food groups in the Hawai'i market are fresh vegetables, other proteins, fresh fruits, and fresh milk.

On a per capita food measurement basis, fresh vegetables again lead with 84.2 kilograms, followed by other proteins at 69.1 kilograms, fresh fruits at 67.7 kilograms, fresh milk at 62.9 kilograms, and rice at 27.9 kilograms. Overall, we estimate the available food per capita for Hawai'i at 657.9 kilograms in 2010. With a reported $\$ 3.68$ billion (2004-2005 dollars) spent on food annually in Hawai $i$, this translates into an inflation adjusted estimate of $\$ 4.52$ billion $^{\mathrm{d}}$ spent on food in 2010 . The average cost of food available in the local market is $\$ 4.66$ per kilogram ( $\$ 4.5$ billion/966.6 thousand tonnes).

\section{Self-sufficiency ratio and import dependency ratio}

Figure 5 shows the SSR of defined food groups and the overall total for Hawai i. It shows that Hawaii has an overall food SSR of $15.7 \%$, and that fresh fruits have the highest level of self-sufficiency among the food groups at $60.4 \%$. Seafood protein follows next at $58.7 \%$ and fresh vegetables at $31.9 \%$. No rice is produced commercially in Hawaii. Finally, the SSR of fresh milk in Hawai'i stands at $12.4 \%$.

Likewise, Figure 6 shows the IDR of defined food groups and the overall total for Hawaii in 2010. Hawai i has an overall food IDR of 102.5\%, and rice has the highest level of import dependency for a food group, at $122.5 \%$. Other proteins follow next, at $101.3 \%$, and other food groups, such as seafood, fresh fruits, fresh vegetables, and fresh milk range from $48.7 \%$ to $87.6 \%$. While the IDR exceeding $100 \%$ is intuitively confusing and appears to be a measurement error, this is not the case here. Rather, it indicates the existence of food imports into Hawai $i$ that are then turned around and re-exported to other markets. Entreport markets, such as Singapore or Israel, consistently exhibited IDR significantly higher than 100\% (Mikic and Gilbert 2007; Gordon 2011). The measures exceeding 100\% are a reflection of re-exports embedded in the raw data collected from official sources. Hence, they do not accurately

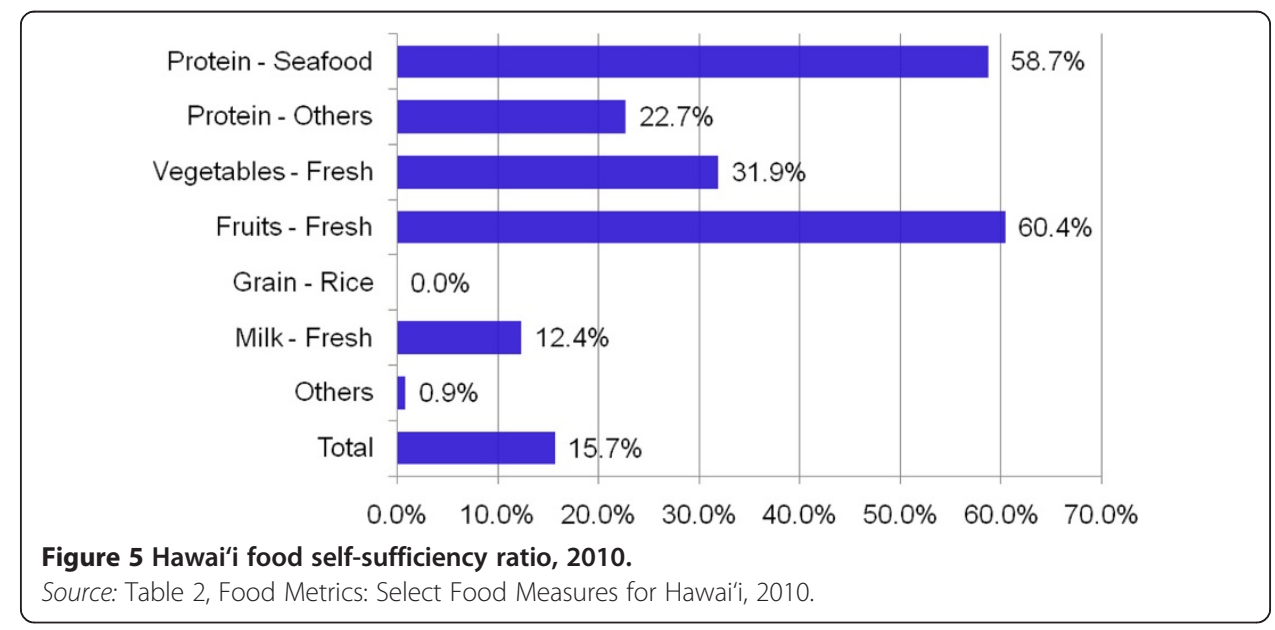




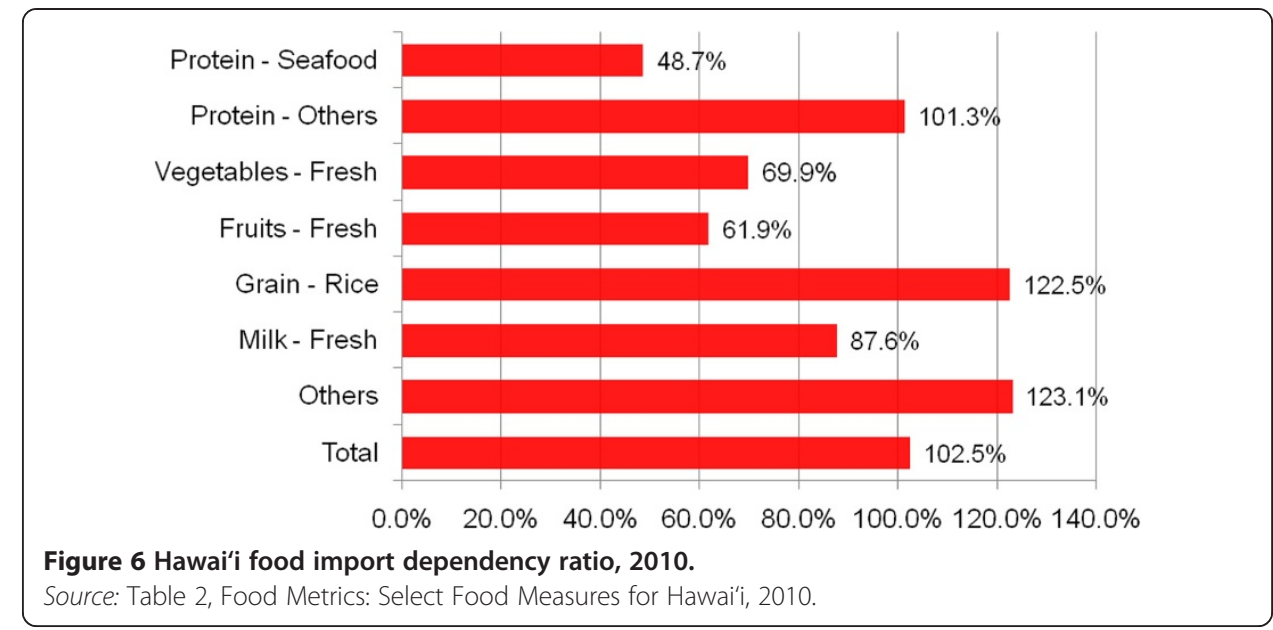

reflect food imports for consumption in Hawai i. Likewise, SSR is clearly not the complement of IDR, as the two figures do not sum to $100 \%$.

\section{A modified set of measurements}

In the previous section, the IDR exceeded $100 \%$. It is clear this measure is biased upwards when re-exports are not accounted for. Likewise, the SSR is biased upwards when exports are not accounted for in the defined food groups. Intuitively, the SSR serves as a better measure of potential local production to satisfy the net demand or local consumption of food. To derive more definitive measures to assess food self-sufficiency and import dependency in Hawaii, we propose to modify the SSR and IDR as follows:

Define $X m=$ re-exports of food imports; and $X p=$ food exports from local production.

$$
\begin{aligned}
S S R^{\prime} & =\frac{P}{P+M-X m-X p} \cdot 100 \%\left(\text { Equation } I^{\prime}\right) \\
I D R^{\prime} & =\frac{M}{P+M-X m-X p} \cdot 100 \%\left(\text { Equation } I I^{\prime}\right)
\end{aligned}
$$

If we take into account the amount of exports from local production, we can redefine Equation I' as the Localization Ratio (LR):

$$
L R=\frac{P-X p}{P+M-X m-X p} \cdot 100 \% \text { (Equation III) }
$$

Similarly, we can redefine Equation II' as the Modified Import Dependency Ratio (MIDR):

$$
M I D R=\frac{M-X m}{P+M-X m-X p} \cdot 100 \%(\text { Equation } I V)
$$

The sum of LR and MIDR (Equation III and Equation IV) is now 100\%:

$$
L R+M I D R=\frac{P-X p+M-X m}{P+M-X m-X p} \cdot 100 \%=100 \%(\text { Equation } V)
$$

Table 2 shows the SSR, IDR, LR and MIDR of defined food groups for Hawaii in 2010. It is worth noting the LR is lower than the SSR in each food group, except for rice, fresh 
milk and others, which remained unchanged, due to the absence of exports from local production. The variation between LR and SSR is progressively larger in food groups with a higher level of exports from local production, e.g. fresh fruits. Likewise, the IDR is biased upwards compared to the MIDR of equivalent food groups, whenever re-exports are not accounted for in the raw dataset. Overall, LR is a more accurate measure on the extent of local food consumption that is sourced from local production, in the absence of stock changes. The total LR estimate indicates only $11.6 \%$ of available food for consumption in Hawai'i was sourced from local production in 2010. Likewise, the MIDR estimate shows 88.4\% of available food in Hawai'i was sourced from imports.

\section{Findings by Major Food Group}

1. Seafood protein: Seafood is a significant component in the food diet of residents in Hawai $i$. On a per capita basis, commercial seafood consumption is estimated at 12.9 kilograms for Hawai $i$, or 1.8 times more than the 7.2 kilograms for the overall United States. This measure increases to 16.7 kilograms when non-commercial (recreational) catch is included. The average equivalent commercial measure for Hawai' $i$ in the 1970s was 9.5 kilograms (Hudgins 1980), about 3.4 kilograms less than current per capita seafood consumption. In general, Hawai'i consumes more fresh and frozen finfish (yellowfin tuna, bigeye tuna and salmon), whereas the rest of the country consumes more shellfish and processed seafood (shrimp and canned tuna).

Seafood supplies are sourced primarily from local and foreign imports.

Collectively, local landings, aquaculture, and noncommercial catch make up 51\% of total available seafood supply in Hawai'i. Foreign imports account for $44 \%$, and imports from the continental United States fill the remaining 5\% (Loke et al. 2012). According to the U.S. Foreign Agricultural Service (FAS), the leading direct foreign sources of seafood imports by weight were from Taiwan, Japan, New Zealand, the Philippines, and the Marshall Islands.

2. Other proteins: Products in this group include red meat (beef, veal, pork, and lamb), poultry (chicken, duck, and turkey), and nuts that are produced locally and imported. In 2010, net supplies from all sources totaled 101 thousand tonnes for this food group. Local production is $9.3 \%$ of total market requirement, and the state

Table 2 Food matrix: select food measures for Hawai'i, 2010

\begin{tabular}{llrrrr}
\hline & Group & SSR & IDR & LR & MIDR \\
\hline 1 & Protein - seafood & $58.7 \%$ & $48.7 \%$ & $51.3 \%$ & $48.7 \%$ \\
2 & Protein - others & $22.7 \%$ & $101.3 \%$ & $9.3 \%$ & $90.7 \%$ \\
3 & Vegetables - fresh & $31.9 \%$ & $69.9 \%$ & $30.1 \%$ & $69.9 \%$ \\
4 & Fruits - fresh & $60.4 \%$ & $61.9 \%$ & $38.1 \%$ & $61.9 \%$ \\
5 & Grain - rice & $0.0 \%$ & $122.5 \%$ & $0.0 \%$ & $100.0 \%$ \\
6 & Milk - fresh & $12.4 \%$ & $87.6 \%$ & $12.4 \%$ & $87.6 \%$ \\
7 & Others & $0.9 \%$ & $123.1 \%$ & $0.9 \%$ & $99.1 \%$ \\
& Total & $15.7 \%$ & $102.5 \%$ & $11.6 \%$ & $88.4 \%$ \\
\hline
\end{tabular}

Sources: Table 1, Hawai'i Total and Per Capita Food Supply, 2010; NASS (2012) Hawai'i statistics. U.S. Department of Agriculture, National Agricultural Statistics Service; and personal communication with local wholesalers and industry analysts. 
is dependent on imports for the remaining 90.7\%, mainly from the continental United States. The Hawaii market supply level in 2010 is about 37\% higher than the 73.9 thousand tonnes in 1980.

Per capita consumption of other proteins (excluding nuts) is estimated at 65.9 kilograms, 19\% lower than the overall United States measure of 78.5 kilograms. This estimate in 2010 is also 4.5\% lower than the per capita estimate of 68.9 kilograms in 1980. The trend in per capita consumption of other proteins (meat) in Hawaii $i$ appears declining slowly over time as consumers switch to healthier, alternate substitutes.

When commercial seafood protein is combined with other proteins (excluding nuts), the combined per capita consumption is 79.1 kilograms in Hawai' $i$, only $8 \%$ lower than the overall United States measure of 85.7 kilograms. This combined estimate in 2010 is marginally lower $(0.9 \%)$ compared to the per capita estimate of 78.4 kilograms in 1980.

3. Fresh Vegetables: Products in this group include leafy and non-leafy greens, sweet corn, tubers (ginger root, potatoes, and taro), and specialty greens that are both grown locally and imported. Net fresh vegetable supplies from all sources totaled 124 thousand tonnes in 2010. Local production is 30\% of total market requirement, and the state is dependent on imports for the remaining $70 \%$, mainly from the continental United States. The market supply in 2010 is about 56\% higher than the 79.4 thousand tonnes recorded in 1980.

Hawai'i's per capita consumption of fresh vegetables is estimated at 84.2 kilograms in 2010, slightly less than the overall United States measure of 84.9 kilograms. In contrast, this estimate is $12 \%$ higher than the per capita estimate of 75.3 kilograms in 1980. The rising trend in per capita consumption of fresh vegetables is likely to continue over time as more residents strive to consume the recommended five servings of fresh fruits and vegetables (FFVs) on a daily basis to increase fiber intake and to realize a healthier diet in their personal lives.

4. Fresh Fruits: Products in this group include tropical fruits grown locally (bananas, guavas, papayas, pineapples, watermelons, etc.) and imported fruits (apples, citrus fruits, berries, stone fruits, etc.). Net fresh fruit supplies from all sources totaled 98 thousand tonnes in 2010. Local production is $38 \%$ of total market requirement, and the state is dependent on imports for the remaining $62 \%$, mainly from the continental United States. The market supply in 2010 is about 2.6 times the equivalent measure of 36.9 thousand tonnes recorded in 1980.

It is worth noting that $37 \%$ of Hawai'i's estimated fruit production of 59 thousand tonnes in 2010 is exported. Should we choose to redirect fresh fruit exports to the local market, we could satisfy $60 \%$ of total consumption requirement.

The per capita consumption of fresh fruits is estimated at 67.7 kilograms, moderately higher (17\%) compared to the overall United States measure of 58 kilograms. This estimate in 2010 is close to double the per capita estimate of 35 kilograms recorded in 1980. Similar to fresh vegetables, the rising trend in per capita consumption of fresh fruits is likely to continue over time as more residents strive to consume five servings of fresh fruits and vegetables (FFVs) each day. Additionally, the rapid growth of tourism in Hawai'i since 1980 has necessitated the increased provision of non-tropical fruits that satisfy the taste preferences of 
visitors. In that same time period, the average number of visitors present per day in Hawai i, increased 85\%, from 96,406 visitors in 1980 to 177,949 visitors in $2010^{\mathrm{e}}$.

5. Fresh Milk: As recently as the early 1980s, Hawai'i produced all fresh milk (dairy) that was consumed in the state. This was a startling achievement, considering only $24.4 \%$ market supply was sourced locally in the 1930s. Since then, a host of less favorable economic circumstances has turned against the industry, wiping out all commercial dairy farms on the island of Oahu, and leaving only two on the island of Hawai i. In 2010, local production supplied $12.4 \%$ of total fresh milk available in the local market. In other words, Hawai' $i$ is $87.6 \%$ dependent on fresh milk imports from outside sources (continental United States).

In 2010, per capita consumption of fresh milk in Hawai'i is estimated at 62.9 kilograms. This is significantly lower than the per capita overall United States consumption of 92.4 kilograms. In 1980, the same measure for Hawaili was 74 kilograms, again lower than the comparable national measure then of 111.4 kilograms. The proportion of per capita fresh milk consumption between Hawai'i and the United States was 0.68 in 2010 and 0.665 in 1980. This difference between Hawai' $i$ and the national measure is historical, and due in large part to the population mix in Hawai i. There is a proportionately large population of residents of Asian descent, many of whom are lactose intolerant, which contributes to a lower propensity to consume fresh milk.

6. Rice: In the conclusion of his 1937 publication, H.H. Warner identified rice as the single most important food item that Hawai'i imports from the outside world. During that period in history, the Territory of Hawai'i produced only $4.1 \%$ of its total rice requirement, and was increasingly threatened by lower cost, mechanized producers in California. Per capita consumption of rice in Hawai'i then was reportedly 40 times higher than in the United States.

Today, there is no known commercial production of rice in Hawai i. We are totally dependent on imports, particularly from the continental United States. About 6\% of the total requirement is foreign imports, mainly specialty rice from Thailand. Over time, per capita consumption of rice in Hawaii declined to an estimated 27.9 kilograms in 2010 from 34.3 kilograms in the mid-1970s. This measure is now only three times more than the 9.6 kilograms per capita consumption in the overall United States.

\section{Discussion}

On a per capita basis, Hawai'i consumes more fresh fruits, rice, and seafood as compared to average consumers in the United States. In contrast, residents in Hawai'i consume less than average United States' residents in food groups such as fresh or chilled meats, fresh milk, and fresh vegetables (marginally less in the latter group). It is plausible that lower consumption of fresh or chilled meats is offset by a higher consumption of canned or processed meats. Anecdotal evidence suggests $\operatorname{SPAM}^{\circledR}$ (luncheon meat) is a local favorite, and Hawai'i has been cited often as the SPAM ${ }^{\circledR}$ capital of the world for its high per capita consumption. Fresh milk consumption has been historically lower as many residents in the local community avoid lactose in dairy milk.

With the 2010 measures currently available, it becomes possible to compare the extent of local consumption arising from local production over time (historical analysis). One of 
the earliest and best documented studies on food sourcing in Hawaii was conducted by the Agricultural Extension Service, University of Hawaii in 1937. This study was conducted with the primary objective of documenting the effects of the Hawai'i maritime strike on food supply in 1936-1937. It found the overall food consumption sourced locally in Hawaii was $37.1 \%$ as measured by product weight between January 1934 to October 1936. The corresponding available food per capita then was 518.3 kilograms, some $27 \%$ lower than the comparable 2010 per capita estimate of 657.9 kilograms.

Likewise, a state Department of Agriculture planning document ${ }^{\mathrm{g}}$ provided equivalent measures for some commodity food groups in 1980. Figure 7 presents a historical comparison of the proportion of food sourced locally by core food groups in Hawai'i in 193436,1980 , and 2010. Ironically, all years reviewed were preceded by a period of tumultuous economic downturn in the United States. The period, 1934-36, marked the official recovery following the Great Depression (August 1929 to March 1933); the first seven months of 1980 saw an enduring Organization of Petroleum Exporting Countries (OPEC) induced recession (January 1980 to July 1980); and 2010 marked the economic recovery in the aftermath of the Great Recession (December 2007 to June 2009) .

While the proportion of overall food sourced locally declined precipitously from $37.1 \%$ in $1934-36$ to $11.6 \%$ in 2010 , falling $25.5 \%$ during the intervening $74-$ year period, the reductions in corresponding core food groups were generally, less dramatic. The two exceptions noted were other proteins and fresh vegetables which dropped $35 \%$ and $30 \%$ respectively. In sharp contrast to the prevailing trend, seafood sourced locally increased by $2.2 \%$ in that same time period.

\section{Lessons learned}

As public discourse on available food for consumption and local production continues in Hawai i, it becomes apparent that state benchmark estimates are required to track market requirements and their supply sources. Food import measures are not readily available and this

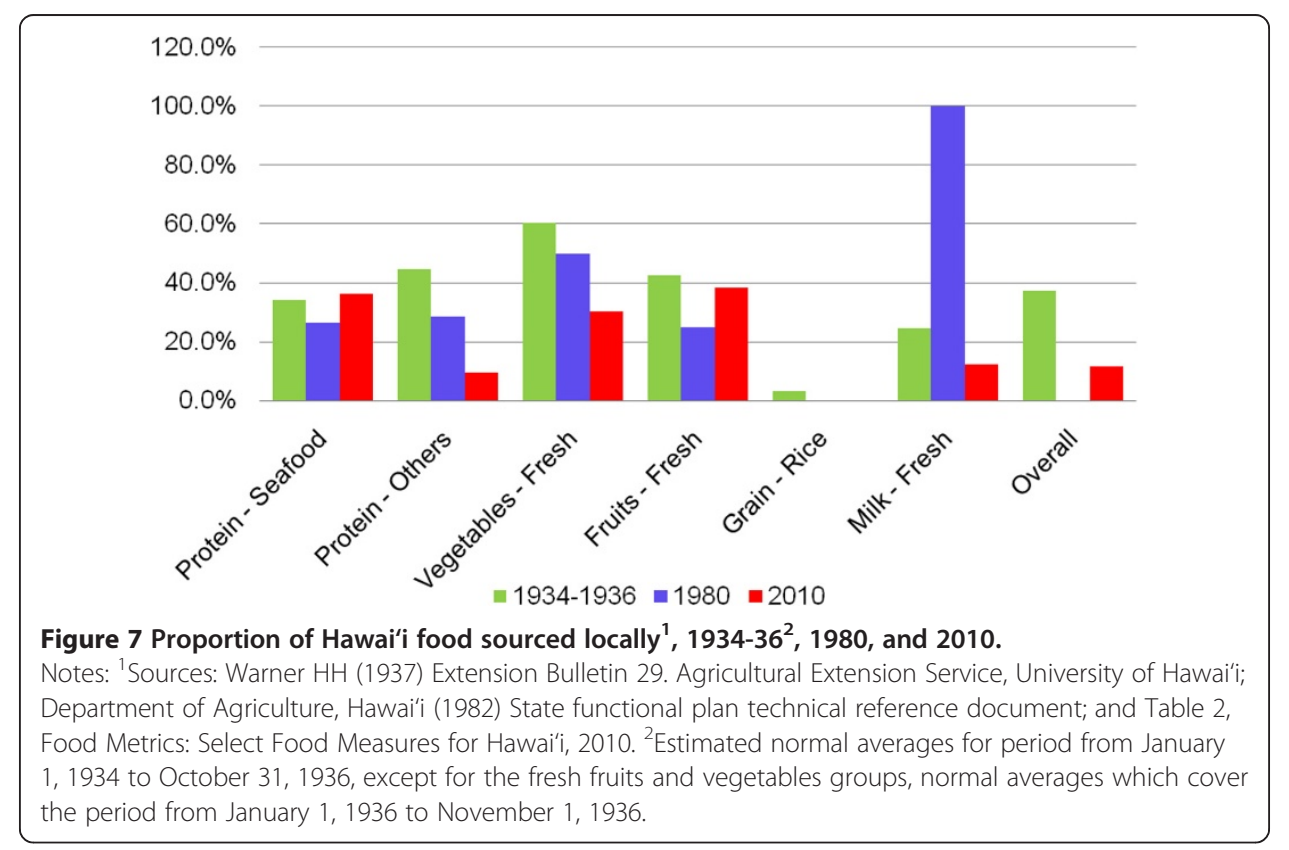


paper is intended to fill that gap by providing a more informed assessment of the market place by bringing together information from published data sources, industry technical reports, and informed industry sources. While the goal is straight forward, the technical efforts required to benchmark the estimates from diverging sources into a meaningful common denominator are far more challenging. The discussion below outlines some of the technical difficulties encountered in this benchmarking effort.

Figure 2 illustrates the blueprint for constructing the food consumption and supply chain flows in Hawai i. With the methodology established, we proceeded to define food groups and sub-groups; select food products for inclusion; and to collate relevant information from core datasets (local production, imports, and exports). The separate procedures and related technical difficulties encountered are expressed as follows:

1. Classification: This initial step is to establish food groups and then break these into finer subgroups whenever possible. Ideally, the groups selected should be defined in the applicable datasets relating to local production, as well as imports and exports (domestic and foreign). A crucial step here is to determine the level of aggregation or disaggregation of food products. An equally important step is to determine the food products to be included or excluded. In this paper, we adopted the major food groups as outlined in the U.S. Department of Agriculture (USDA) My Plate concept - dairy, grains, protein, fruits, and vegetables (Figure 1). Subgroups are also designated, such as for protein - seafood, beef, veal, pork, other meats, and nuts; and fruits - fresh, frozen, dried and prepared. To facilitate meaningful comparisons with other established metrics, we excluded beverages (coffee, tea, water, malt extracts, wine, spirits, liqueur, beer, etc.), seeds and spores, and live animals.

2. Standardization: Once classification is complete, the task of compiling, aggregating and converting the many food products with different unit measures into a common unit measure begins. Various databases and data sources utilize different measuring units. American databases such as NASS, adopt measuring units ranging from pounds, short tons, gallons, and actual units (number of eggs or heads of cattle). At the local production level, there are various product settings such as harvested, utilized, processed or dressed. International databases (foreign imports and exports) adopt the metric system and report measures ranging from kilograms, metric tons (tonnes), liters, kiloliters, and actual units.

Furthermore, the conversion of volume measure to weight measure, for instance kiloliters to pounds or gallons to kilograms, requires knowledge of the specific liquid's density. For example, one liter of water (at 4 degrees Celsius) is about one kilogram and converts to about 2.2 pounds, whereas one liter of olive oil is about 0.92 kilogram and converts to about 2.02 pounds. Finally, it is important to convert the measurement of food items to their most consumable form. For example, livestock products are defined in dressed weight as opposed to live weight and seafood is defined in edible weights as opposed to product weight. Overall, this procedure can be competently accomplished with more resources, particularly, with relevant datasets.

3. Reconfiguration: When specific items from various datasets or data sources are not available or not clearly delineated, it is necessary to reconfigure the initially defined food groups and subgroups. In this study, we were not able to differentiate canned, dried or processed, fruits and vegetables. Hence, we reconfigured fruits and vegetables to fresh 
fruits and fresh vegetables. The same challenge confronts grains and dairy. Hence, we redefined them as rice (grains) and fresh milk (dairy). All the undifferentiated products were aggregated into the residual (catch all) food group "Others." By reconfiguring the food groups/subgroups, we can provide meaningful comparative metrics to the overall benchmarking process.

4. Validation: This crucial procedure assesses how significant and relevant the various compiled statistics and estimates are in the various food groups. The rationality and consistency tests within and across time frames are important to establish the validity of the information presented. Various challenges that lurk around the corner include double counting and benchmarking against inappropriate/misleading industry metrics, including metrics that are ill defined.

Double counting is a real hazard when reconfiguring the various foodgroups/subgroups, redistributing the weight measure of various food products, and in measuring processed (value-added) products. The same challenge is encountered when aggregating outshipment (export) volumes from various island ports. Summing up volumes from each island port will lead to double counting since a large volume of exports are shipped to Honolulu before being shipped to the continental United States. Secondly, out-shipment from Honolulu, can also imply in-shipment to neighbor island ports.

Inappropriate/misleading industry metrics can arise when specific local commodity measures are estimated by utilizing per capita national measures (as opposed to state or local) as proxies. This practice skews the estimate of total commodity production away from its true value. The unique composition of Hawai'i's population does not always lends itself to similar consumption patterns of residents in other American states. We have established that Hawaiti residents consume more seafood (1.8 times), more rice ( 3 times) but less fresh milk (1/3 times) when compared to all United States residents on a per capita basis. Finally, only comparable measures with similar definitions should be utilized for validating estimated measures. In this paper, we included nuts in the protein food group and this food item is retracted when comparing red meat and poultry, the standard for defining protein at the national level by USDA.

While we make estimates at different levels, it is assumed the databases or data sources are credible and reasonably accurate, at least at the higher (aggregated) level. Hence estimates at the higher level are more robust than those at the lower (disaggregated) level. Plainly, the sum of all food groups across each dataset or data source is more complete than the sum of food subgroups or products that may be missing in one or more dataset or data source.

\section{Conclusions}

This paper establishes a set of benchmark estimates on food available for market consumption and its supply sources in Hawai'i. Overall, we estimated the total food available at 966.6 million kilograms, or a per capita consumption of 657.9 kilograms in 2010. Fresh vegetables, other proteins, and fresh fruits were the leading defined food groups. The vast majority of this available food is imported from the continental United States $(81 \%)$, with $6 \%$ from foreign countries. 
In assessing the extent of food localization in Hawai $i$, we adopted the SSR and its complementary measure, the IDR. Hawai'i had an overall food SSR of $15.7 \%$ and an overall food IDR of $102.5 \%$ in 2010 . Obviously, the two complementary measures do not sum up to $100 \%$. This result led us to conclude that SSR was a better measure of "potential" local production to satisfy local market consumption of food in Hawai'i. Likewise, the IDR exceeding 100\% indicates the existence of food imports that are then turned around and re-exported to other markets.

To provide a more accurate assessment of food localization, we suggested two modified measures of self-sufficiency and import dependency, namely the localization ratio (LR) and the modified import dependency ratio (MIDR). The overall LR estimate reveals that only $11.6 \%$ of available food for consumption in Hawai'i was sourced from local production in 2010. Likewise, the MIDR estimate shows $88.4 \%$ of available food in Hawai'i was sourced from imports. Beyond that, we have also established that the consumption patterns of some food groups are quite different for residents in Hawai'i than for those in the overall United States.

As a final point, a historical comparison of total food consumption suggests that Hawai'is per capita measure increased to 657.9 kilograms in 2010, as compared to only 518.3 kilograms in 1936. However, Hawai'i had a lower proportion of food sourced locally in 2010, with a localization ratio (LR) of $11.6 \%$; this is much lower compared to the ratio of $37.1 \%$ in 1936. Within defined food groups, Hawai'i had a higher LR in seafood in 2010 than in 1936. Lower LRs were recorded for the remaining food groups defined.

The analytical framework presented in this paper can be applied to other small, open (island or regional) economies with a food localization agenda, as it provides a more discrete and appropriate set of measurements, as well as offering the lessons gained through Hawai'i's experience and challenges in the data-collating process. Additionally, the procedures and food groups defined are particularly applicable to island economies, which are less resource endowed in the production of grains and are far too often neglected in mainstream studies on food self-sufficiency.

With the metrics and benchmark estimates now realized, there are potential implications for food policy decisions in Hawai i. Since the SSR and LR rely on both local production (supply) and market consumption of food (demand), it may not be optimal for the state to establish an arbitrary annual target measure for food localization. First, agricultural production fluctuates substantially from year to year, usually constrained by periods of drought, heavy rain and floods, and other force majeure events. Likewise, food consumption is subject to fluctuations over time, usually influenced by changes in consumer preferences and income. Secondly, it may enhance the state's welfare to support the cultivation of certain food groups for which Hawai'i has a comparative advantage in production and taste preference and which are substitutes for products that require a large volume of imports. One clear example is seafood, which can be substituted for other protein products. At a different level of self-sufficiency, it may be advantageous to support the exports of certain food groups and not divert them into local markets. Clearly, earnings from the export of tropical fruits (pineapples, papayas, avocados) can be utilized to fund the imports of temperate-climate fruits such as apples, citrus, and stone fruits. Likewise, the export of sweet potatoes, fish, and basil can be exchanged for rice imports. Agricultural export earnings can also be utilized to purchase needed factor inputs such as fertilizers, pesticides, packaging materials, and farm implements. 
Finally, the logical extension for continuing research in Hawai'i's food supply and consumption matrix is to expand the defined food groups and subgroups and to further delineate them into food forms such as dried, canned, or processed. Furthermore, it is equally appropriate to assess the various food groups and subgroups that have the greatest potential to achieve a higher degree of food localization in Hawai'i. The additional knowledge arising from such an assessment could further alleviate many of the concerns expressed by Hawai'i residents as to the vulnerability of the state's food supply chain in the midst of continuing volatility in global markets.

\section{Endnotes}

aWarner HH (1937) Hawai'i's food supply and the maritime strike of 1936-37. Extension Bulletin 29. Agricultural Extension Service, University of Hawai'i.

bHawaii's rapid urbanization is well reflected in Honolulu's growing traffic congestion. See Honolulu StarAdvertiser (Apr 04, 2013) Honolulu third-worst for traffic congestion. http://www.staradvertiser.com/news/breaking/20130404_Honolulu_thirdworst_for_traffic_ congestion.html?id=201473771 Accessed 9 Apr 2013.

${ }^{\mathrm{c}}$ All data sources utilized in this table are reported in quantities (usually weight measures available) and not in other metrics (e.g., dollars, calories or nutrition values). The weights used consistently here are as reported and have not undergone conversions, except for eggs and poultry (unit count to product weight and live to dressed weight). Seafood is reported in edible weight as sourced verbatim from a previous study (conversions from product to edible weight).

${ }^{\mathrm{d}}$ This estimate is derived from CPI-U Honolulu (Food and Beverages), Table 14.4 (2004, 2005, and 2010), State of Hawai'i Databook from a base value of $\$ 3.68$ billion, sourced from the BLS Consumer Expenditures Survey, 2004-2005.

${ }^{\mathrm{e} S}$ See 2011 State of Hawai'i Databook. Table 7.03, Visitors arrival and average daily census: 1966 to 2011.

${ }^{\mathrm{f}}$ This is according to Lee and Bittenbender (2008) Agriculture. Paper for Hawai'i sustainability 2050. College of Tropical Agriculture and Human Resources, University of Hawai'i at Manoa.

${ }^{\mathrm{g}}$ DOA (1982) A state functional plan technical reference document. Department of Agriculture, Hawai'i.

${ }^{\mathrm{h}}$ Respective timelines are sourced from the National Bureau of Economic Research (NBER) at http://www.nber.org/cycles.html Accessed 12 Dec 2012. 
No. 58-5320-7-664). Finally, we acknowledge invaluable assistance from numerous industry contacts in sharing information pertinent to this project.

Received: 31 January 2013 Accepted: 2 July 2013

Published: 27 August 2013

\section{References}

ACE-WCSC (2012) Navigation data center - domestic U.S. waterborne traffic, part 4, 2010. U.S. Army Corps of Engineers. Waterborne Commerce Statistics Center, New Orleans, LA. http://www.navigationdatacenter.us/wcsc/webpub10/ webpubpart-4.htm. Accessed 16 Jul 2012

De Janvry A, Sadoulet E (1991) Food self-sufficiency and food security in India: Achievements and contradictions. In: Ruppel FJ, Kellogg ED (ed) National and regional self-sufficiency goals. Lynne Rienner, Boulder \& London

DEFRA (2006) Food security and the UK: An evidence and analysis paper. UK. Department for Environment, Food and Rural Affairs, London. http://archive.defra.gov.uk/evidence/economics/foodfarm/reports/documents/foodsecurity. pdf. Accessed 5 Apr 2013

DEFRA (2008) Food statistics pocket book 2008. U.K. Department for Environment, Food and Rural Affairs, London. http://webarchive.nationalarchives.gov.uk/20130123162956/http:/www.defra.gov.uk/statistics/files/defra-statsfoodfarm-food-pocketbook-2008.pdf. Accessed 5 Apr 2013

FAO (2001) Food balance sheets - A handbook. Food and Agricultural Organization of the United Nations, Rome. http://www.fao.org/docrep/003/x9892e/x9892e00.htm. Accessed 26 Oct 2012

FAS (2012) Global agricultural trade system (GATS) U.S. Department of Agriculture, Foreign Agricultural Service, Washington D.C. http://www.fas.usda.gov/gats/defaultaspx. Accessed 12 Jun 2012

Fitzpatrick E (1991) Agricultural self-sufficiency in Southeast Asia: Malaysia and Thailand. In: Ruppel FJ, Kellogg ED (ed) National and regional self-sufficiency goals. Lynne Rienner, Boulder \& London.

Gordon U (2011) Program for an assessment of food sustainability in Israel. Arava Institute for Environmental Studies, Ketura, Israel. http://www.arava.org/userfiles/file/Director/_Food.doc. Accessed 5 Apr 2013

Halweil B (2004) Eat here: Reclaiming homegrown pleasures in a global supermarket. W.W. Norton \& Co., New York

Heady D, Fan S (2008) Anatomy of a crisis: the causes and consequences of surging food prices. Agricultural Economics. 39:375-391

Holm D, Rogers R, Lass D (2000) Food self-sufficiency in the New England states, 1975-1997. Department of Resource Economics, University of Massachusetts, Amherst, MA. http:/www.massbenchmarks.org/publications/studies/pdf/ foodself00.pdf. Accessed 26 Oct 2012

Hudgins L (1980) Per capita annual utilization and consumption of fish and shellfish in Hawai'i, 1970-77. Marine Fisheries Review. 42:16-20

Kako T (2009) Sharp decline in the food self-sufficiency ratio in Japan and its future prospects. Paper presented at the International Association of Agricultural Economists Conference, Beijing, China. 16-22 August 2009

Kendall P, Petracco M (2009) The current state and future of Caribbean agriculture. Journal of Sustainable Agriculture. 33(7):780-797

Leung PS, Loke M (2008) Economic impacts of improving Hawaili's food self-sufficiency. Economic Issues El-16 (December 2008). College of Tropical Agriculture and Human Resources, University of Hawaili at Manoa, Honolulu, HI. http://www.ctahr.hawaii.edu/oc/freepubs/pdf/El-16.pdf. Accessed 12 Dec 2012

Loke M, Geslani C, Takenaka B, Leung PS (2012) Seafood consumption and supply sources in Hawai'i, 2000-2009. Marine Fisheries Review 74(4):44-51

Melrose J, Delparte D (2012) Hawai'i county food self-sufficiency baseline 2012. University of Hawai'i, Hilo, HI. http:// geodata.sdal.hilo.hawaii.edu/GEODATA/COH_Ag_Project.html. Accessed 26 Oct 2012

Mikic M, Gilbert J (2007) Trade statistics in policymaking: A handbook of commonly used trade indices and indicators. Economic and Social Commission for Asia and the Pacific (ESCAP), Bangkok, Thailand. http://www.unescap.org/tid/ aptiad/Handbook2.pdf. Accessed 11 Jan 2013

NASS (2012) Hawai'i statistics. U.S. Department of Agriculture, National Agricultural Statistics Service, Washington D.C. http://www.nass.usda.gov/Statistics_by_State/Hawaii/index.asp. Accessed 2 Jul 2012

OP-DBEDT (2012) Increased food security and food self-sufficiency strategy. Office of Planning, Department of Business, Economic Development and Tourism, Hawai'i. http://files.hawaii.gov/dbedt/op/spb/INCREASED_FOOD_SECURITY_ AND_FOOD_SELF_SUFFICIENCY_STRATEGY.pdf. Accessed 12 Dec 2012

Page C, Bony L, Schewel L (2007) Island of Hawai'i whole system project phase I report. Rocky Mountain Institute, Boulder, CO. http://www.kohalacenter.org/pdf/hi_wsp_2.pdf Accessed 26 Oct 2012

Ulupono I (2011) Local food market demand study of O'ahu shoppers: Executive summary. https://dl. dropboxusercontent.com/u/40878762/Local\%20Food\%20Market\%20Demand\%20Study\%20Executive\%20Summary. pdf. Accessed 12 Dec 2012

doi:10.1186/2193-7532-1-10

Cite this article as: Loke and Leung: Hawail's food consumption and supply sources: benchmark estimates and measurement issues. Agricultural and Food Economics 2013 1:10. 